\title{
Diversity In The International Charity Sector
}




\section{Glossary}

\begin{tabular}{|c|c|c|}
\hline$\#$ & Term & Description \\
\hline 1 & BME / BAME & Black and Minority Ethnicity, \\
\hline 2 & IR & International Relations \\
\hline 3 & ID & International Development \\
\hline 4 & SDIP & $\begin{array}{c}\text { Summer Diversity Internship } \\
\text { Programme (SDIP) }\end{array}$ \\
\hline 5 & EDIP & $\begin{array}{c}\text { Early Diversity Internship } \\
\text { Programme }\end{array}$ \\
\hline
\end{tabular}




\section{Development studies is fun, but is there a job [for everyone?] (Duncan Green)}

\section{Introduction}

Like the majority of my childhood friends, my parents were both immigrants from Ghana, the importance of education was instilled in me and my siblings from a very young age. I attended my local, state-funded secondary school in North London which had daily occurrences of violence against teachers and peers, with a $20 \%$ pass rate. To counter the lack of classroom learning, my parents worked extra hours to put us through Saturday school, particularly for English and Maths. Despite this, my dream was to work for the UN and my parents insisted that my surroundings didn't matter, that if you get your A levels, go to a "good university", you will eventually get the job that you want.

My grades were in the top $5 \%$ and this consequently resulted in me being admitted into one of the top selective colleges in the borough. I am now a Civil Servant but have witnessed and heard of many obstacles along the way that both my peers and I have faced. I believe that a combination of perseverance, confidence, parental support and being at the "right place at the right time" has helped in assisting my journey. I studied international Relations at undergraduate level; after graduating from my first degree, I got a sales job to save up for my MSc. Apparently, it's impossible to get a job in that field without masters and it was certainly a requirement for many internships I was attracted to. I had the idea, like many others, that once I had all the credentials, first degree from a "good university", and 2nd degree from a "good university" I would get the magical job at the UN and would be set, why wouldn't I be? I worked hard like I was told, got "good" grades and made sure to keep abreast of extracurricular activities.

Along the way, however, there were a few red flags, I was constantly hearing "if you want to get into international development you need to volunteer" or "make use of your already existing network and ask for any opportunities (I couldn't really afford to volunteer and culturally my parents wouldn't class that as working, also I didn't know anyone in the field). This wasn't shocking as I was applying for loads of unpaid jobs but still wasn't getting them, I did manage to get a paid UN internship, but again, that was due to lots of perseverance, Linkedln invitations as well as forward planning. Once you land an internship, however, there is a constant battle to renew your contract and look for work. Ironically, whilst at the UN, I attended loads of conferences on precarious work and what individual nations could do to help battle this, but something was telling me that we were still a long way away from making this field both sustainable and accessible to all.

I jumped on the bandwagon of temporary consultancy work, internships, and graduate programmes to gain valuable paid experience. I do believe that this would not have been possible if I had not had a stable home to fall back on in between roles, something we can take for granted. I participated in a graduate scheme which involved a stint in the Cabinet Office, I worked in Brussels, which was quite an interesting time but also got me thinking about my career path and the fact that despite my academic experience (BA, MSc, Diploma and PRINCE 2), and my exposure to the most prominent institutions in my field, the jobs I really wanted, a paid international charity job with field experience, was extremely difficult to secure.

Upon reading Oxfam's From Poverty to Power, there was a very interesting article by Duncan Green titled "Development Studies is fun, but is there a job at the end of it?" with an amusing illustration of the graduation line feeding into the unemployment line. This inspired both the title of this article and a true investigation into the disparities of those who study certain courses and those who end up in 
sustainable employment. After investigating, it seemed as though certain parts of society find it very easy to get jobs whilst the rest face an uphill battle. Social mobility was lacking, but those from BME backgrounds were disproportionately affected, the sector is criticised for being too "white, male and middle class" (Wright 2013).

\section{Background}

The issue of racial diversity in charities has gained momentum but even more so over the past year, with a focus on charity boards, there has been significant attention on race and gender. Research by inclusive boards finds that the charity sector is far behind the private sector.

- "Charities have fewer staff from BAME backgrounds than either the public or private sectors" (Ainsworth 2018a).

- $6.6 \%$ of trustees being from an ethnic minority background - this compares to $8.2 \%$ on FTSE 100 boards.

- Almost $80 \%$ of senior leadership teams lack any ethnic minority professionals.

- $62 \%$ of the UK's largest charities have all white boards.

- ACEVO's Pay and Equalities Survey found that only 3\% of charity chief executives were from BAME backgrounds, a percentage that has fallen over the last ten years.

- 50 largest fundraising charities, found that only $12 \%$ of chief executives, $6 \%$ of senior managers were from BAME backgrounds.

- Charity Job's survey found that 54\% of BAME candidates said they'd experienced discrimination on account of their race or ethnicity. The figures rose even more for women who are black and over 50 .

There is some movement to solving these issues. ACEVO and the Institute of Fundraising are requesting charity leader's sign up to eight principles to improve diversity and inclusion, if we select a few, we can see their significance; charities must:

- Acknowledge that there is a problem with racial diversity in the charity sector and commit to working to change that.

- Commit to action and invest resources, where necessary, in order to improve racial diversity in my charity.

- Commit to setting permanent and minimum targets for diversity that reflects the participants, donors, beneficiaries and the population of the area that my charity operates.

- View staff as the sum of many parts rather than a single entity and recruit to build a diverse group of talented people collectively working towards a shared vision.

The focus on graduates, however, is very limited. Dame Mary Marsh, the founding director of the Clore Social Leadership Programme, which provides social leaders with leadership development programmes, is a key contributor to this particular debate, stating that charities are reliant on "informal internships" as opposed to the "formal recruitment process". Her review of Skills \& Leadership in the VCSE Sector pinpoints some areas which need to be addressed. She states that the sector adversely affects those who cannot afford internships and for hiring (even at entry-level) a degree of experience is required "This is partly because the sector lacks clear starting or entry points" (Marsh 2013:19).

She suggests the third sector develop routes to entry for 16 - 19-year-olds, like Apprenticeships, as well as the invention of graduate schemes for the sector that mirror Teach First. There is currentlya 
movement on this. Charity Works, one of the few non-profit sector's graduate programmes has over 150 partners, with a guaranteed salary between $£ 18,300-£ 21,300$ and a separate programme for BME candidates, unfortunately, only $\mathbf{2} \%$ of the partners are UK based, international development charities.

This is significant because the largest and more prestigious organisations like Amnesty International, recruit unpaid interns with the expectation of them working in their International Secretariat offices in famously expensive cities like London, Geneva and New York. In addition, the British Red Cross offers 8-12 week-long unpaid internships and Oxfam, unpaid internships lasting between three and six months. This would inevitably create social mobility and racial inequalities, but even more sobering is the genuine belief that the charity sector as a whole, even though regulated by the charity commission, is not accountable to the public. "They are less accountable than a trade union general secretary or a chief executive officer in an FTSE-listed company... exist[ing] in an area where there is no apparent democratic structure (Kay 2016:1). As a result, we can only make assumptions about the organisational culture of the sector.

One assumption comes from Ainsworth (2018a), he argues that a majority of the workforce is, especially at the entry-level, taken from those with a degree and that in itself creates disparities:

"Less people from BAME backgrounds graduate in those subjects, particularly with good degrees from Russell Group universities. So if the sector recruits proportionately, charities will end up with an unrepresentatively white workforce." (Ainsworth 2018a:1).

Ainsworth (2018a) touches on two issues here, how many from BME backgrounds are accepted into or even apply to "good" universities but even more relevant to this report, when we analyse those that take subjects like International Development or International Relations, does the pool become smaller?

\section{Methodology}

I approached the relevant authorities to gain access to data ${ }^{1}$ that would allow for a critical evaluation of the disparities between BME and Non-BME UK domiciled students; once I processed the data, it was obvious that assumptions had become fact.

\footnotetext{
${ }^{1}$ The Rounding Methodology has been a pplied.
} 
Figure 1: BME representation across UK HE Providers for International Relations and International Development at undergraduate level

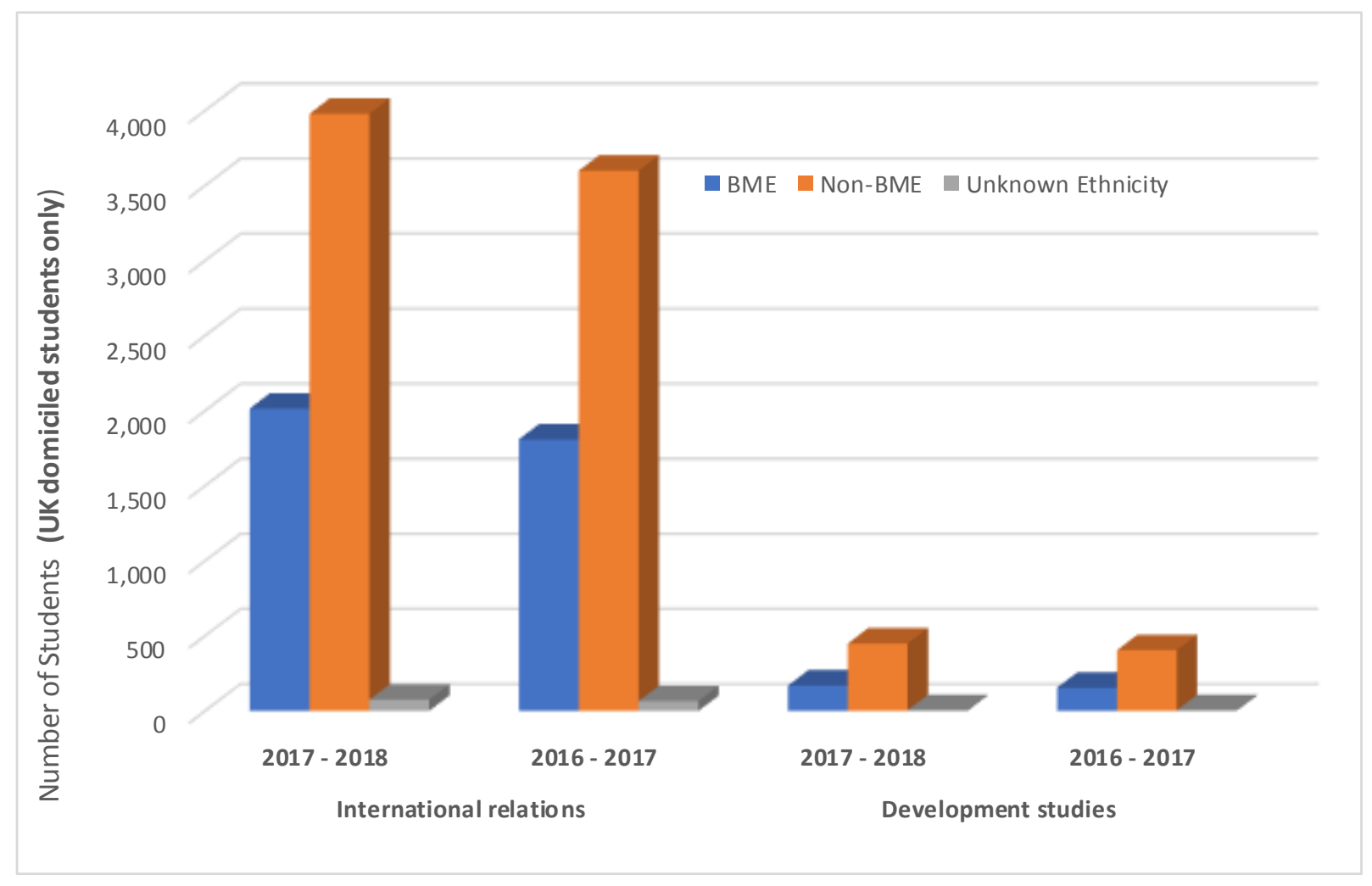

HESA (2019) 
Figure 2: BME representation across UK HE Providers for International Relations and International Development at Masters Level

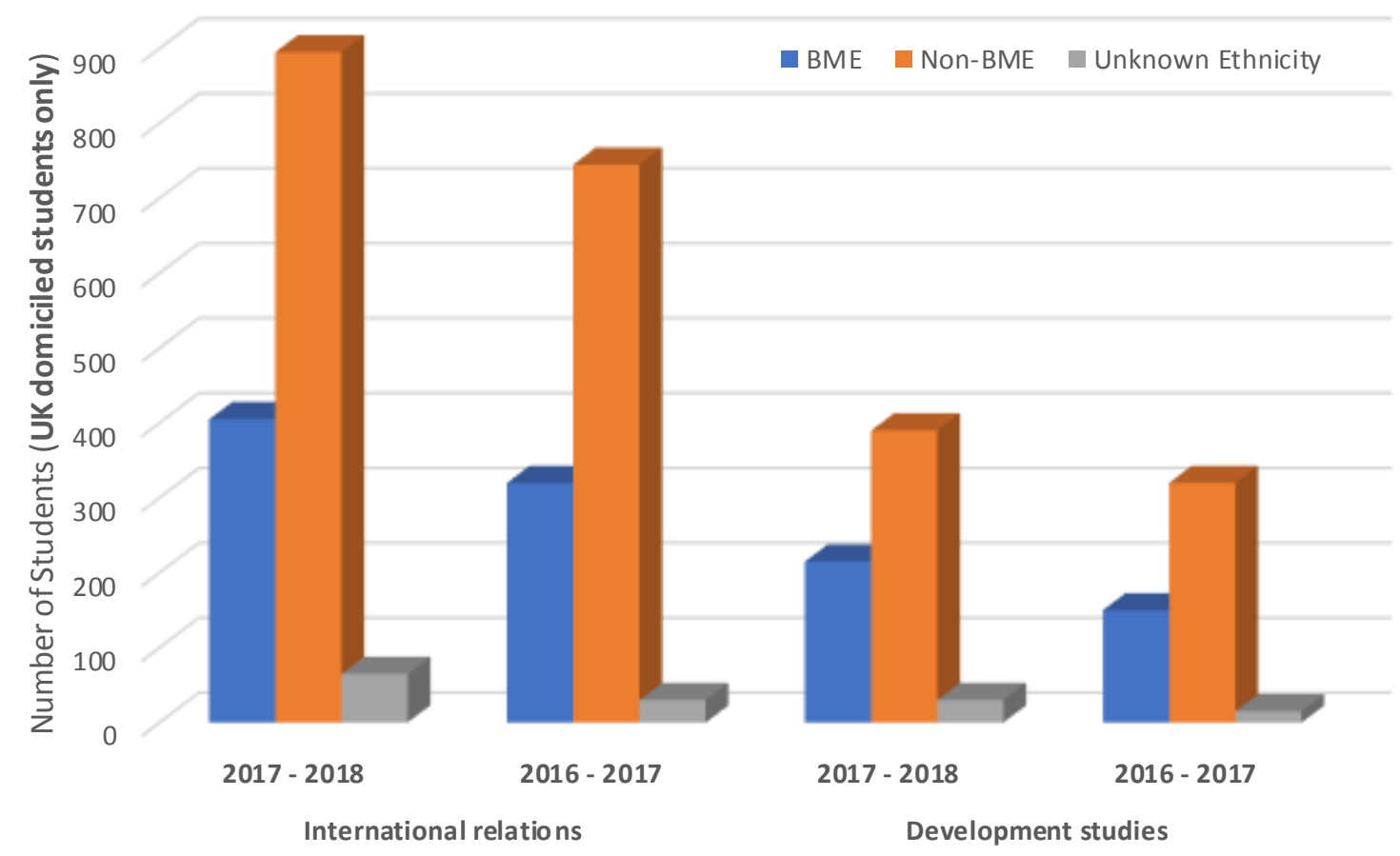

HESA (2019) 
From figures 1 and 2, we can see that the disparities are clear, if we look at the most recent figures of UK domiciled students from 2017/2018 for an Undergrad in Development Studies, we can see that you are over $\mathbf{1 6 0 \%}$ less likely as a BME candidate to take the course.

The figures lead me to reflect on my own decision, as well as questions that came up when choosing to study IR at the undergrad level. The decision was very much influenced by my interest in politics, international relations, and war and peace; if Kofi Annan could "make it" so could I.

The questions that came up were very much related to the culture I came from. Not only was I warned that I had to outperform my peers in order to be considered average, this course for me was very much outside the expectations of what the daughter of African immigrants should pursue, it was outside the practical subjects that would as many believe, guarantee a job like engineering, law or medicine.

\section{Figure 3: BME representation across UK HE Providers for leavers securing roles in international organisations and bodies.}

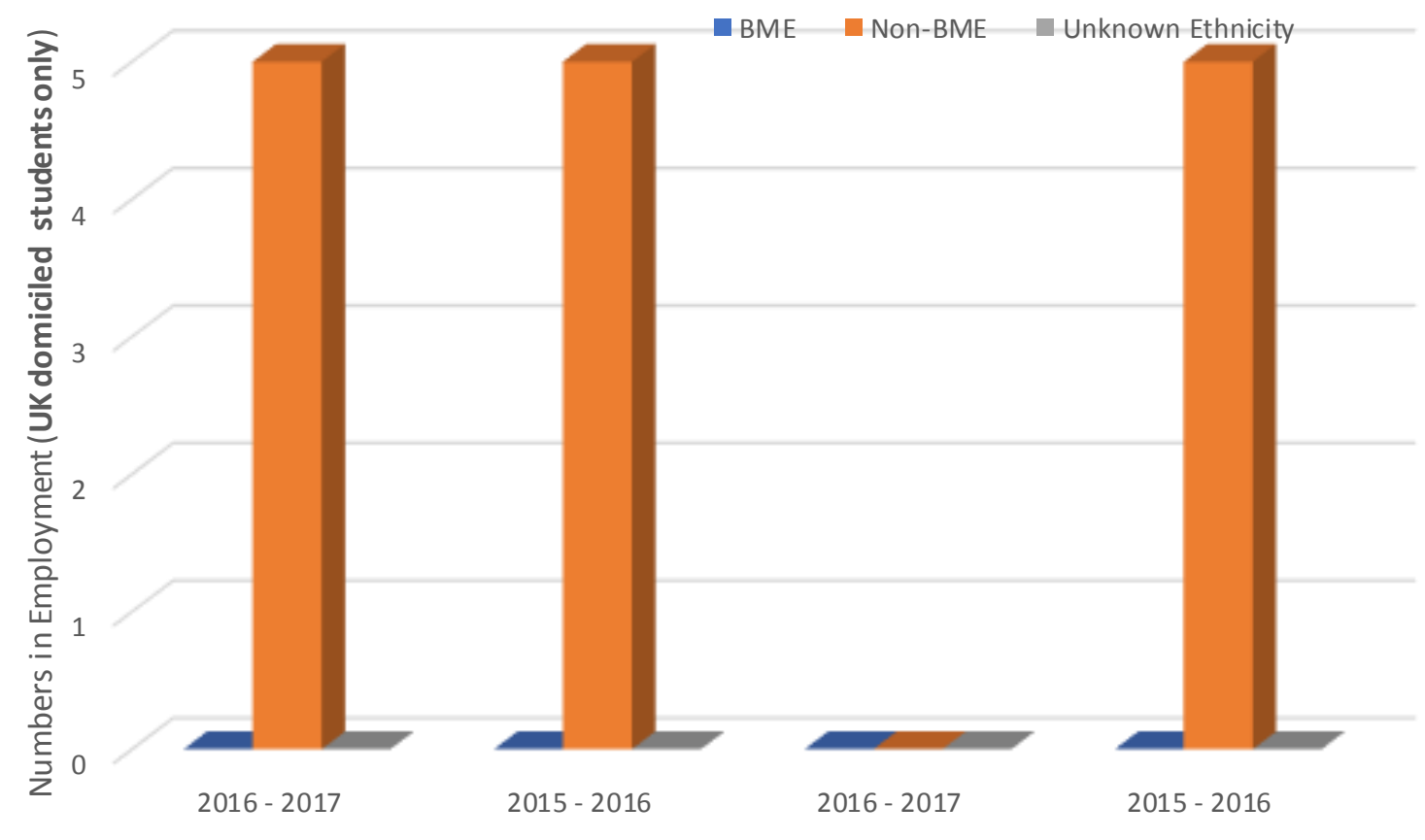

International relations

Development studies

HESA (2019) 
This brings us to analyse the work situation. What paths do these graduates take after studying? When we look at figure 3 above, we can see that the situation, although dire for all that take the course, is especially dire for those from a BME background, they are disproportionately $600 \%$ less likely to secure a role in a relevant organisation.

Figure 4: BME representation across UK HE Providers for Undergraduate s who register as unemployed.

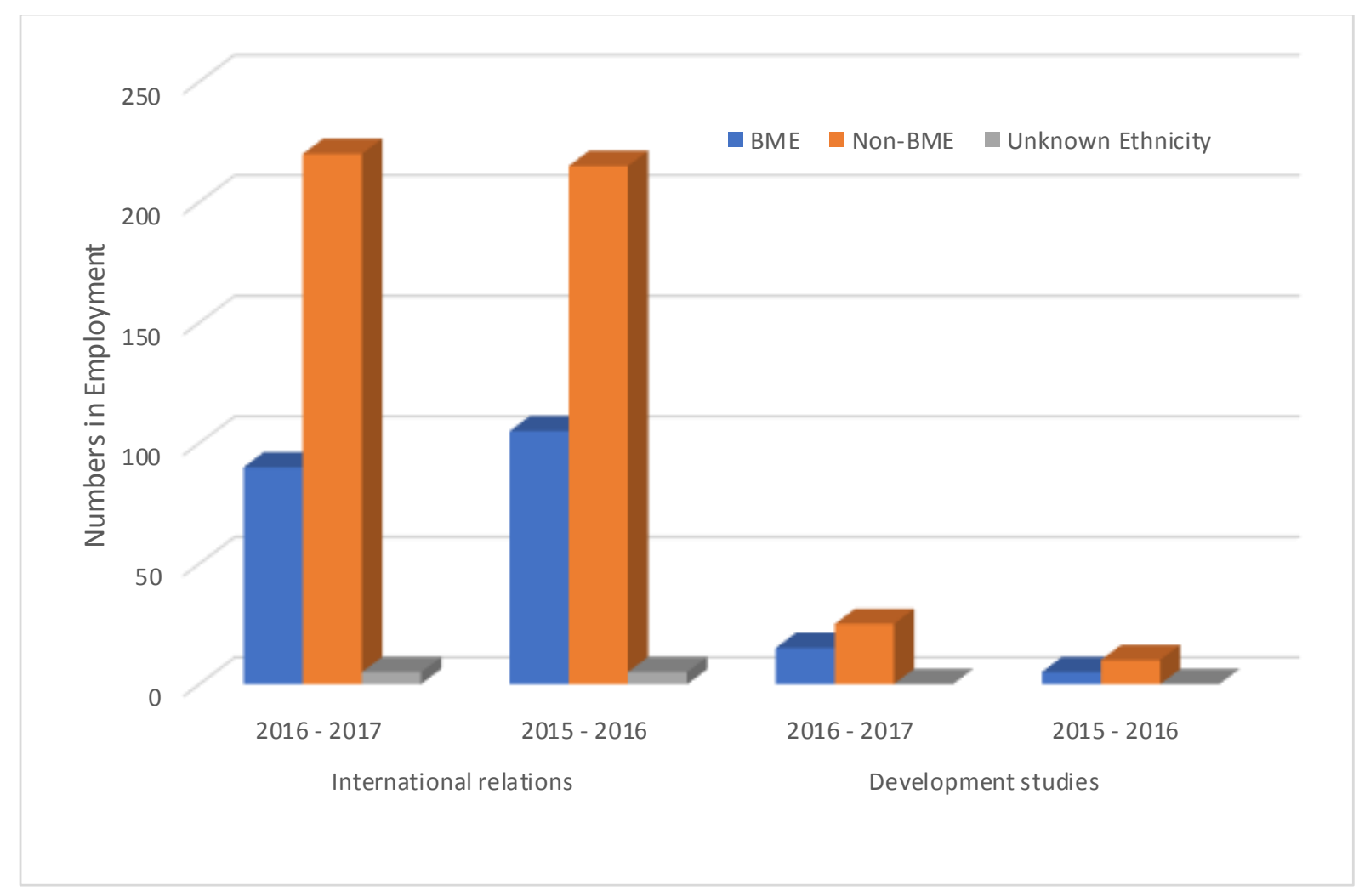

HESA (2019) 


\section{Figure 5: BME representation across UK HE Providers for Masters graduates who register as unemployed.}

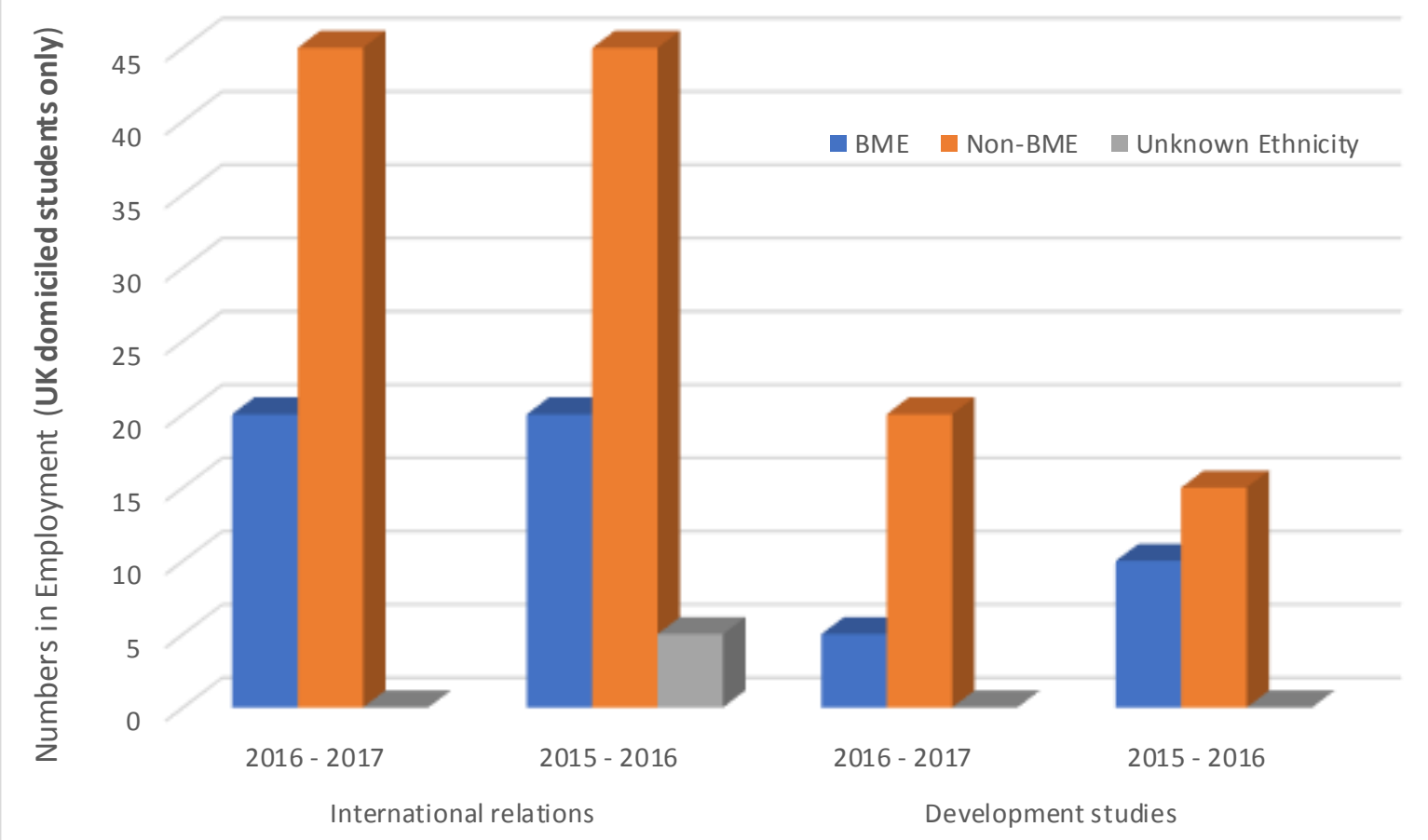

HESA (2019)

\section{Findings}

Employment statistics in figures 4 and 5 above also make for compelling findings. Although BME candidates are significantly less likely to take either course or be offered a relevant job (over $160 \%$ and $600 \%$ respectively) those who are recognised as Non - BME are on average, twice as likely to be registered as unemployed.

It could be argued that cultural norms, socioeconomic status, and perseverance to get the preferred route to entry are key players, however, what cannot be ignored is the charity sector. Those working in the charity sector as volunteers or interns and are unpaid are classed as unemployed. In order to get a true picture of what happens to graduates, where they end up and how long for, further analysis is needed. To complement the data that already exists, we must also look at the diversity of entrylevel professions in the charity sector, more specifically, a full review of the ethnic demographics of volunteers and interns of UK - based international development charities, data which at present is not monitored by the Charity Commission.

The policy recommendations listed below are a combination of adaptations from existing policy, and innovative ideas to improve the disparities. 


\section{Policy recommendations:}

- Charity Commission to conduct an analysis of ethnic demographics of volunteers and interns of UK - based international development charities.

- Cabinet Office to execute a cross-departmental initiative similar to that of the apprenticeship commitment: Public procurement of contracts with direct links to charities/foundations and private sector bodies in the international development sector to implement targeted work experience placements.

- Candidates can either be targeted via a separate talent pool, or the pool of SDIP/EDIPers.

- Charity sector to implement name-blind recruitment to help alleviate unconscious bias

- A review of the relevance of ID and IR to employers - the relevance of IT and social media.

\section{Conclusion}

There will always be a question as to why this topic matters, why now and perhaps why at all. It is worth mentioning that the US and the UK have the lowest social mobility rates of the West, yet whilst the US has remained stable, the UK has declined (The Sutton Trust 2019).

The international development sector can do more to ensure that charities reflect the diversity of the communities which they serve. Whether this is by the implementation of affirmative action and become the "over-employer[s]" of people from disadvantaged backgrounds" (Ainsworth 2018a:1). Or sign up to the eight principles mentioned above or simply offering paid work.

Additional research is needed to truly understand the scale of the problem, for the BME candidates who studied ID at undergrad, we do not know their individual employment timelines.

This social mobility story has focused on a small proportion of a wider issue of social mobility and BME recruitment in the UK. It goes far beyond this sector and leaks into other industries such as legal and architecture, hence the creation of the Miranda Brawn Diversity Leadership Foundation, as well as the Society of Black Architects founded by Elsie Owusu (OBE RIBA).

It also reaches far to the international level. In 2015, I wasn't at all shocked to come across the story of a UN intern David Hyde who was sleeping in a tent beside Lake Geneva because he simply couldn't afford to live there, (Croxford 2018). This was later discovered to be a campaign rather than reality, however, what is real are the colleagues I met in Brussels sleeping in abandoned buildings and rummaging through supermarket bins in hope of food not yet past its sell-by date. Or in Geneva, extortionate rent, friends with heavy bank loans without the guarantee of work and the general belief that this is the only way into international development.

Finally, after 50 years, the World Health Organisation has committed to paying its interns, only a small proportion, $25 \%$ come from low-income countries and in a bid to increase this to $50 \%$ by 2020 , the agency has agreed to provide financial assistance (Croxford 2018).

The title of my social mobility story is "Development studies is fun, but is there a job for everyone?" Currently, the answer to these questions depends, it depends on who you know, where you studied, what country you live in and in the UK, what colour you are. 
In an ideal world, there would be a movement towards creating a course which ensures everyone is employable, secondly significant movement to ensure that the sector is not only racially, but socially diverse. The policy recommendations are the first step.

If we're ever going to make progress beyond the current situation, all stakeholders, academics, charities, the private sector, the government needs to work together to change the dynamics not only in the UK but globally. 


\section{Further reading.}

ACEVO (2019) Staff and trustee diversity targets, Available from:

https://www.acevo.org.uk/diversity/staff-and-trustee-diversity-targets

ACEVO (2019) Racial diversity in the charity sector, Available from: https://www.acevo.org.uk/2018publications-and-reports/racial-diversity-charity-sector

Ainsworth, D. (2018a) Why is the charity sector so white? Available from https://www.civilsociety.co.uk/voices/david-ainsworth-why-is-the-charity-sector-sowhite.html\#sthash.loEyE8RZ.dpuf

Ainsworth, D. (2018b) Should Charities be more accountable to the public? Available from https://www.civilsociety.co.uk/voices/david-ainsworth-should-charities-be-more-accountable-tothe-public.html

Charity Works, Available from www.charity-works.co.uk/join-our-network

Cooney, R. (2018) Charity boards less diverse than UK's biggest companies, says report, Available from: https://www.thirdsector.co.uk/charity-boards-less-diverse-uks-biggest-companies-saysreport/governance/article/1462582

Croxford, R. (2018) UN agency's U-turn after unpaid internships row, Available from: https://www.bbc.co.uk/news/world-45605768

Green, D. (2018) Development Studies is fun, but is there a job at the end of it?, Available from: https://oxfamblogs.org/fp2p/development-studies-is-fun-but-is-there-a-job-at-the-end-of-it/

HESA (Higher Education Statistics Agency), Available from: https://www.hesa.ac.uk/

Kay, L. (2016) Charities 'out of touch' and 'accountable to no one', says Tory peer. Available from: https://www.thirdsector.co.uk/charities-out-touch-accountable-no-one-says-tory-peer/policy-andpolitics/article/1408426

Inclusive boards (2016) Charities: Inclusive Governance, Available from: https://www.inclusiveboards.co.uk/charity-governance-2018/

Marsh, M. (2013) Skills and leadership in the VCSE sector: Dame Mary Marsh Review, London, Cabinet Office, Available from: https://www.gov.uk/government/publications/skills-and-leadershipin-the-vcse-sector-dame-mary-marsh-review

Salmom, A (2016). Charities are accountable to their beneficiaries. Available from: http://thirdforcenews.org.uk/blogs/charities-are-accountable-to-their-beneficiaries 
The Charity Commission (2017) Taken on Trust: awareness and effectiveness of charity trustees in England and Wales, Available from: https://www.gov.uk/government/publications/taken-on-trustawareness-and-effectiveness-of-charity-trustees-in-england-and-wales

Weakley, K. (2018) Leaders urged to sign up to eight principles because charities are 'failing' on diversity, Available from: www.civilsociety.co.uk/news/leaders-urged-to-sign-up-to-eight-principlesbecause-charities-are-failing-on-diversity.html\#sthash.aSC1QYOp.dpuf

Wright, O. (2013) Charities are "too white, too male, too middle class" Review says diversity in recruitment and promotion should become a priority, Available from:

https://www.independent.co.uk/news/uk/politics/charities-are-too-white-too-male-too-middleclass-review-says-diversity-in-recruitment-and-promotion-8617850.html

Pay your interns foundation, (2019) List of NGOs who offer paid internships, Available from: https://payyourintern.com/list-of-ngos-who-offer-paidinternships/?fbclid=IwAR2HDRaNIjrt5CBZDJQk22UveHoaeeQ2Twd1UCEXiQaKU214i1EggAnFLEc

The Sutton Trust (2019) Disturbing finding from LSE study - social mobility in Britain lower than other advanced countries and declining, Available from:

https://www.suttontrust.com/newsarchive/disturbing-finding-lse-study-social-mobility-britainlower-advanced-countries-declining/ 